\title{
Special Issue in Connection with Professor John O. Krog's 65th Birthday
}

\section{PROFESSOR, DR. PHILOS. JOHN KROG}

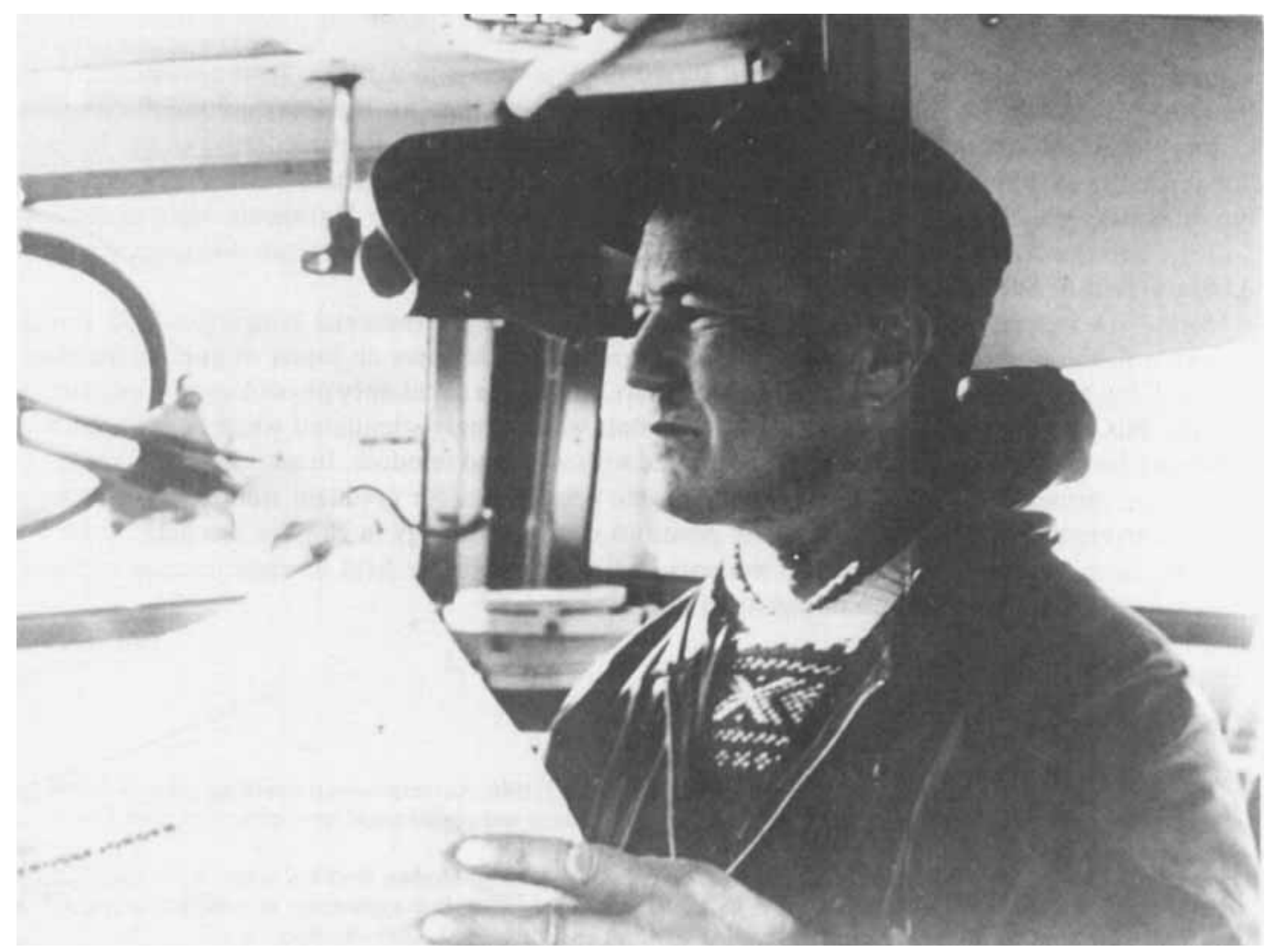

John Krog was born in Meldal, Norway on the 29th of August, 1918. He graduated (cand. real.) at the University of Oslo in 1949, with zoology as his major subject, and in 1964 obtained his doctorate at the same university.

John Krog worked as a biology teacher at Oslo Teachers' College in 1950 before spending four years working as a physiologist with Professor Lawrence Irving in Anchorage, Alaska, under the Exchange Visitor's Program, U.S. Public Health Service. From 1954 until 1964 he worked at the Institute for Experimental Medical Research, Ullevål Hospital, Oslo, first as Research Fellow in Circulatory Physiology and from 1962 as Associate Professor. He was Visiting Research Professor at the Department of Physiology and Biophysics, University of Kentucky Medical School, Lexington, Kentucky, U.S.A. from 1964 to 1965 and was appointed Professor and Chairman of the Institute of Zoophysiology, University of Oslo, in 1965. 
During leave from these positions, John Krog extended his qualifications through short stays in other research institutions. He studied circulatory physiology and polarographic oxygen determination under Dr. H. C. Bazett and Professor H. Montgomery. University of Pennsylvania; microcirculation under Dr. Benjamin Zweifach, University of Boston, and Professor E. Bloch, Western Reserve University: circulatory physiological methods and problems connected with adaptability to cold under Professor Otto Edholm, National Institute for Medical Research, London; and problems concerning vasodilatation due to cold at the University of Gothenburg.

John Krog has participated in several scientific expeditions. He spent six months in Panama making physiological studies on counter-current principles (1956-57). In Finnmark, Norway, he studied acclimatization to cold in Lapps and fishermen (1957-58). He went with Alpha Helix to the Bering Sea (1968), was the leader of an expedition to Greenland to study blood circulation of the Eskimos (1968), and made two expeditions to Enare, Finland, for studies on adjustments to cold in the Skolt Lapps (1969-70).

John Krog is a member of the Editorial Board of Acta Microcirculatoria; he is a member of the National Committee for Biophysics, the Constitutional Committee for the International Biophysical Union, the Scientific Committee on Oceanographic Research, and is a Representative of the International Union of Physiological Sciences. He has membership in the Scandinavian Association of Physiologists, the Scandinavian Society for Clinical Physiology, the European Microcirculatory Society, and the Aerospace Medical Association; he is a fellow of the American Association for the Advancement of Science and of the Arctic Institute of North America.

During his career, John Krog has attended a number of international congresses and several symposia in the capacitv of guest speaker. He has also given lectures on topics of popular science.

John Krog has published about 80 scientific papers, mainly on circulatory physiology and adaptation to cold. His interest in the biology of arctic animals was strongly stimulated when he worked with Lawrence Irving in Alaska. He later experimented with seals and reindeer. In addition to his research, John Krog promoted zoophysiology, extending the possibilities for graduate studies in this subject at the University of Oslo. Most university positions in zoophysiology in Norway are held by former students from his institute. Graduate students and scientists in the field of experimental medicine have also benefited from his encouragement and advice.

Ola B. Reite

\section{List of publications}

Krog, J. 1953: Notes on the birds of Amchitka Island. Alaska. The Condor 55, 299.

Irving, L. \& Krog. J. 1954: Body temperatures of arctic and subarctic birds and mammals. J. Appl. Physiol. 6. 667

Krog. J. 1954: Improved needle thermocouple for subcutaneous and intramuscular temperature measurements in animals and man. Rev. Sci. Instrum. 25. 799.

Krog. J. \& Simmet. R. 1954: An attachment for the low-power binocular microscope facilitating observations at controlled temperatures. Trans. Am. Microscop. Soc. LXXXX. 4

Krog. J. 1954: Storing of food items in the winter nest of the Alaskan ground squirrel. Citellus undulatus. J. Mammal. 35. 586.

Krog. J, 1954: The influence of seasonal environmental changes upon the metabolism. lethal temperature and rate of heart beat of Gammarus limnaeus (Smith) taken from an Alaskan lake. Biol. Bull 107. 397

Irving. L. \& Krog J. 1955: Temperature of skin in the Arctic as a regulator of heat. J. Appl. Physiol. 7.4.

Krog. J. 1955: Notes on temperature measurements indicative of special organization in Arctic and Subarctic plants for utilization of radiated heat from the sun. Physiol. Plant. 8 . 836.
Krog. J. 1956: An inexpensive temperature controlled room for clinical and physiological investigations. J. Oslo City Hosp. 6.76.

Krog, J. 1956: Modern electrical temperature measurements and some of their applications in experimental physiology and medicine. J. Oslo City Hosp. 6. 117.

Storm-Mathiesen, A. \& Krog. J. 1956: Skin resistance measurements: A comparative study of the results obtained by using the Regelsberger and Kaiser apparatus. J. Oslo City Hosp. 6. 77 .

Krog, J. 1956: Thermistor hypodermic needle for subcutaneous temperature measurements. Rev. Sci. Instrum. 27, 408.

Irving. L. \& Krog. J. 1956: Temperature during the development of birds in arctic nests. Physiol. Zool. $X X I X$, no 3 .

Erikson. H. \& Krog. J. 1956: The critical temperature in naked man. Acta Physiol. Scand. 37. 35.

Scholander, P. F., Lange Andersen, K. \& Krog, J. 1957: Critical temperature in lapps. J. Appl. Physiol. 10, 231.

Krog. J. \& Scholander, P. F. 1957: Countercurrent vascular heat exchange. with special reference to the arteriovenous bundles in sloths. Acta Physiol. Scand. 42, suppl. 145.

Scholander. P. F. \& Krog, J. 1957: Countercurrent heat exchange and vascular bundles in sloths. J. Appl. Physiol. 10. 405 . 
Lund, I., Johansen, K., Krog, J. \& Birkeland, S. 1958: The change in vascular resistance of the dog's brain on perfusion with cold blood and modifying effect of $\mathrm{CO}_{2}$ and Trimsta plancamphor-sulphonate (Arfonad). Acta Anaesth. Scand. 2,149 .

Krog, J. \& Johansen, K. 1959: Construction and characteristics of tefloncovered polarographic electrode for intravascular oxygen determination. Rev. Sci. Instrum. 30, 108.

Birkeland, S. Vogt, A., Krog, J. \& Semb, C. 1959: Renal circulatory occlusion and local cooling. J. Appl. Physiol. 14 , 227.

Johansen, K. \& Krog, J. 1959: Diurnal body temperature variations and hibernation in the Birch-mouse, Sicista betulina. Am. J. Physiol. 196, 1200.

Birkeland. S., Krog, J., Vogt, A. \& Semb, C, 1959: Renal function following ischemia under renal hypothermia. $J$. Appl. Physiol. 14, 227

Krog. J. 1959: Notes on rectal temperature variations in dogs during Nembutal anaesthesia. Acta Physiol. Scand. 45, 308.

Johansen, K. \& Krog, J. 1959: Peripheral circulatory response to submersion asphyxia in the Duck. Acta Physiol. Scand. 46, 194.

Johansen, K. \& Krog, J. 1959: Polarographic determination of intravascular oxygen tension in vivo. Acta Physiol. Scand. $46,228$.

Kristiansen, K., Krog, J. \& Lund, I. 1959: Experiences with selective cooling of the brain. Acta Chir. Scand. Suppl. 253, 151.

Krog, J. \& Johansen, K. 1960: The relation between muscular blood flow and oxygen tension as measured polarographically. Acta Chir. Scand. Suppl. 253, 162

Semb, C., Krog, J. \& Johansen, K. 1960: Renal metabolism and blood flow during local hypothermia, studied by means of renal perfusion in situ. Acta Chir. Scand. Suppl. 253, 196.

Krog, J., Folkow, B., Fox, R. H. \& Lange Andersen, K. 1960: Hand circulation in the cold of lapps and north Norwegian fishermen. J. Appl. Physiol. 15, 654.

Andersen. P.. Johansen, K. \& Krog, J. 1960: Electroencephalogram during arousal from hibernation in the birch-mouse. Am. J. Physiol. 199, 535

Aukland, K. \& Krog, J. 1960: Renal oxygen tension. Nature 188. 671 .

Folkow. B., Fox, R. H., Krog, J., Odelram, H. \& Thoren, O. 1960: An analysis of the vascular response to intense cooling. Acta Physiol. Scand. Suppl. 175, 1.

Aukland, K. \& Krog, J. 1961: Influence of various factors on urine oxygen tension in the dog. Acta Physiol. Scand. 52, 350 .

Kristiansen, K. \& Krog, J. 1962: Electromagnetic studies on the blood flow through the carotid system in man. Neurology 12,1 .

Krog, J. \& Kristiansen, B. 1962: A new filter unit for extracorporeal circulation. J. Oslo City Hosp. 12, 108.

Ingebrigtsen, R.. Krog, J. \& Leraand, S. 1962: Velocity and flow of blood in the femoral artery proximal to an experimental arterio-venous fistula. Acia Chir. Scand. 124. 45.

Krog, J. 1962: Effects of cervical sympathetic stimulation on cerebral circulation. Excerpts Medica, International Congress Series, no. 48 .

Krog, J., Leraand, S., Kristiansen, B. \& Kristiansen, K. 1962: A servooperated perfusion unit for selective cooling of the brain. J. Oslo City Hosp. 12, 238.

Krog, J. 1963: Electrical measurement of body temperature. Acta Anaesth. Scand. Suppl. XI, 99.

Folkow, B., Fox, R. H., Krog, J., Odelram, H. \& Thoren, O.
1963: Studies on the reactions of the cutaneous vessels to cold exposure. Acta Physiol. Scand. 58, 342.

Krog, J. \& Amundsen, B. 1963: A simple instrument for measurement of onset of claudication symptoms in patients suffering from atherosclerosis of the lower limbs. J. Oslo City Hosp. 13, 31.

Ingebrigtsen, R., Krog, J. \& Leraand, S, 1963: Circulation distal to experimental arterio-venous fistulas of the extremities. Acta Chir. Scand. 125, 308.

Fänge, R., Krog, J. \& Reite, O. B. 1963: Blood flow in the avian salt gland studied by polarographic oxygen electrodes Acta Physiol. Scand. 58, 40.

Fänge, R. \& Krog, J. 1963: Inability of the kidney of the hagfish to secrete phenol red. Nature 199, no. 4894. 713 .

Krog, J. \& Reite, O. B. 1963: The circulatory effect of bradykinin in birds. Acta Physiol. Scand. 59, suppl. 213.

Reite, O. B., Krog, J. \& Johansen, K. 1963: Notes on the development of bradycardia during submersion of the duck. Nature 200, 684.

Krog. J. 1963: Oxygen Supply in Aquatic Forms. Pergamon Press, Oxford.

Krog, J. 1963: The use of polarographic oxygen tension measurements for estimation of rapid changes in regional blood flow. J. Oslo City Hosp. 13, 65.

Krog, J. 1963: The effect of cervical sympathetic stimulation on cerebral blood flow in birds. J. Oslo City Hosp. 13, 201.

Krog, J. 1963: The effect of cervical sympathetic stimulation on cerebral blood flow in the rabbit. J. Oslo City Hosp. 13. 185

Irving, L., West, G. C. \& Krog, J. 1964: Changes in water content of arctic plants during winter. Science in Alaska, 37.

Johansen, K., Krog, J. \& Reite, O. B. 1964: Autonomic nervous influence on the heart of the hypothermic hibernator. Annales Acad. Scient. Fenn. Series A. IV Biologica 71, 17.

Carlson, L. D. \& Krog, J. 1965: Effects of subpressures applied to the lower part of the human body. Proc. of the XXIII International Congress of Physiological Sciences, 73.

Murray, R., Krog, J., Carlson, L. \& Rowers, J. 1965: Lower body negative pressure as a provocative test for the circulatory system. The Physiologist 8, 238.

Krog, J., Cohn. J. \& Shannon. R. 1965: The effect of water immersion upon the cardio-pulmonary functions in the goose. Proc. of the American Physiological Society Fall Meeting, Los Angeles.

Reite, O. B., Krog, J. \& Carlson, L. D. 1965: Influence of noradrenaline on vascular resistance in the intact perfused ears of coldadapted and warmadapted rabbits. Proc. of the International Symposium on Enviromental Physiology.

Wyndham, C. H., Morrison, J. F., Krog, J. \& Carlson. L. D. 1965: Standardization of methods for estimating body tolerance to cold. Proc. of the International Symposium on Enviromental Physiology. Japan.

Murray, R. H., Krog, J., Carlson, L. \& Bowers. J. A. 1966: Cumulative effects of venesection and negative pressure applied to the lower body. Rep. from Aerospace Medicine. $37,1$.

Smith, R. E. \& Krog, J. 1966: A peltier effect heat exchanger appropriate for temperature regulatory studies in small animals. Arctic Aeromed. Lab. 6.

Krog, J. 1966: Physiological adaption to arctic living in the nomad lapps. Physical Activity in Health and Disease, 262.

Krog, J. \& Smith, R. E. 1967: Miniature peltier effect heat exchanger for extracorporeal circulation. J. Appl. Physiol. $22,2$.

Murray, R. H., Krog, J., Carlson, L. D. \& Bowers, J. A. 1967: 
Cumulative effects of venesection and lower body negative pressure. Aerospace Medicine 38(3), 243-247.

Cohn, J. E., Krog, J. \& Shannon, R. 1968: Cardiopulmonary responses to head immersion in domestic geese. J. Appl. Physiol. 25. 1.

Krog. J. 1968: Forslag til metodikk for bedømmelse av den perifere sirkulasjonstilpassing til kuldc hos mennesker. Nordisk Medicin 79, 414.

Krog, J. A Álvik. M. \& Lund-Larsen. K. 1969: Investigations of the circulatory effects of submersion of the hand in ice water in the Finnish Lapps. the Skolts. Federation Proceedings. Vol. 28.3

Krog. J.. Reite, O. B. \& Fjellheim. P. 1969: Vasomotor responses in the growing antlers of the reindeer. Rangifer tarandus. Nature 223. 99-100.

Iversen. J. A. \& Krog. J. 1972: Body temperatures and resting metabolic rates in small petrels. Norw. J. Zool. 20. 141-144.

Iversen. J. A. \& Krog. J. 1972: Body temperatures in active and resting charadriiforme birds (murres, puffins and auklets) at different ambient temperatures. Norn: J. Zool. 20. 145146.

Iversen. J. A. \& Krog. J. 1973: Heat production and body surface area in seals and sea otters. Norw. J. Zool. 21. 5154.

Krog. J. 1975: Människans anpassning till kaltt klimat. Finska Läkaresällskapets Handlingar Årg. 135. Band 119. 11-13.

Krog. J.. Wika. M. Lund-Larsen. T., Nordfjell. J. \& Myrnes. I. 1976: Spitsbergen reindeer. Rangifer tarandus platy $h v n$ chus Vrolik. Morphology. fat storage and organ weights in the late winter season. Norw. J. Zool. 24, 407-417.

Ringberg. T. Jacobsen. E.. Ryg. M. \& Krog. J. 1977: Seasonal changes in levels of growth hormone, somatomedin and thyroxine in free-ranging. semi-domesticated Norwegian rein- deer (Rangifer tarandus tarandus (L.)). Comp. Biochem. Physiol. 60A. 123-126.

Krog. J. 1979: Vascular studies by means of external application of negative pressure. J. Oslo City Hosp. 29, 119-121.

Krog. J., Zachariassen, K. E., Larsen, B. \& Smidsrød, O. 1979: Thermal buffering in Afro-alpine plants due to nucleating agent induced water freezing. Nature 282, 300-301.

Wika. M. . Krog. J. \& Bjarghov. R. 1979: Thermoregulation in newborn reindeer calf. In: Abstracts from $X V I$ Scand. Congress of Physiology and Pharmacology, Oulu.

Pàsche. A. \& Krog. J.1980: Heart rate in resting seals on land and in water. Comp. Biochem. Physiol. 67A, 77-83.

Krog. J. . Wika. M. \& Savalov, P. 1980: The development of the foetus of the Norwegian reindeer. Pp. 306-310 in Reimers. E., Gaare, E. \& Skjenneberg, S. (eds.): Proc. 2nd Int. Reindeer/Caribou Symp., Røros, Norway. Direktoratet for vilt og ferskvannsfisk, Trondheim.

Wika, M. \& Krog. J. 1980: Antler 'disposable vascular bed'. Pp. 422-424 in Reiners, E., Gaare, E. \& Skjenneberg, S. (eds.): Proc. 2nd Int. Reindeer/Caribou Symp.. Røros, Norway. Direktoratet for vilt og ferskvannsfisk, Trondheim.

Wika. M. \& Krog, J. 1980: Thermoregulation and brown adjpose tissue in the newborn reindeer calf. Pp. 425-431 in Reimers, E.. Gaare. E. \& Skjenneberg, S. (eds.): Proc. 2nd Int. Reindeer/Caribou Symp., Røros, Norway. Direktoratet for vilt og ferskvannsfisk. Trondheim.

Wika. M. 1980: On growth of reindeer antlers. Pp. 416-421 in Reimers. E.. Gaare. E. \& Skjenneberg, S. (eds.): Proc. 2nd Int. Reindeer/Caribou Symp., Røros, Norway. Direktoratet for vilt og ferskvannsfisk. Trondheim.

Wika, M. \& Krog, J. 1980: The vascular bed of reindeer antler. Proc. IUPS vol. XIV, XXXVIII Int. Congress, Budapest. 